\title{
ASUHAN KEPERAWATAN PSIKOSOSIAL PADA WANITA DEWASA DALAM MERAWAT PASIEN COVID DENGAN TERAPI DZIKIR
}

\author{
${ }^{1}$ Larasuci Arini \\ ${ }^{2}$ Setiadi Syarli \\ ${ }^{3}$ Siti Mungawanah \\ Institut Kesehatan Mitra Bunda \\ Email:larasuci.arini78@gmail.com
}

\begin{abstract}
ABSTRAK
Covid -19 penyakit menular yang disebabkan oleh tipe baru coronavirus dengan gejala umumnya demam, kelemahan, batu, kejang, dan diare. Tujuan pemberian asuhan keperawatan ini adalah untuk mengatasi cemas pada wanita dewasa yang merawat pasien covid melalui terapi dzikir. Asuhan Keperawatan ini dilaksanakan selama tiga hari dari tanggal 25-27 Oktober 2020. Metode penelitian yang di gunakan pada asuhan keperawatan ini adalah studi kasus yang di lakukan berdasarkan tahapan asuhan keperawatan meliputi pengkajian, diagnosa, intervesi, implementasi dan evaluasi keperaawatan. Hasil dari asuhan keperawatan ini di dapatkan dua diagnosa yaitu ansietas berhubungan dengan perubahan status dan gangguan pola tidur berhubungan dengan faktor eksternal cemas/takut. Adapun intervensi yang diberikan pada pasien dengan masalah yang prioritas yakni ansietas adalah dengan terapi dzikir. Hal ini bertujuan untuk mengurangi ansietas yang dialami klien selama merawat pasien covid, dan terlihat setelah diberika terapi dzikir selama tiga hari. Harapan setelah memberikan asuhan ini agar seluruh perawat ruangan yang beragama Islam dapat menerapkan terpai non farmakologis terapi dzikir untuk menurunkan ansietas selama bertugas merawat pasien covid.
\end{abstract}

\section{Kata kunci : askep, wanita, Covid 19, Psikososial, Dzikir}

\begin{abstract}
Covid -19 an infectious disease caused by a new type of coronavirus with common symptoms of fever, weakness, stones, seizures, and diarrhea. The purpose of providing nursing care is to overcome anxiety in adult women who treat covid patients through dhikr therapy. This nursing care was carried out for three days from 25-27 October 2020. The research method used in nursing care is a case study which is carried out based on the stages of nursing care including assessment, diagnosis, intervention, implementation and evaluation of nursing. The results of this nursing care obtained two diagnoses, namely anxiety associated with changes in status and disturbances in sleep patterns associated with external factors of anxiety / fear. The intervention given to patients with priority problems, namely anxiety, is the dhikr therapy. This aims to reduce the anxiety experienced by clients while treating Covid patients, and can be seen after being given dzikir therapy for three days. It is hoped that after providing this care, all room nurses who are Muslim can apply non-pharmacological dzikir therapy to reduce anxiety while caring for Covid patients.
\end{abstract}

Key words: Covid -19, Psychosicial, Dzikir 


\section{PENDAHULUAN}

Indonesia bahkan Dunia saat ini sedang berada dalam masa berduka akibat adanya Pandemi Covid 19. Pandemi ini merupakan bencana non alam. Kondisi bencana non alam yang luas dan menyeluruh seperti saat ini membutuhkan peran serta semua lapisan masyarakat dalam upaya pencegahan maupun penanganannya. Peran serta masyarakat yang dapat dilakukan salah satunya dengan menjadi tenaga relawan bencana Virus corona(Agustin 2020).

Covid-19 penyakit menular yang disebabkan oleh tipe baru coronavirus dengan gejala umum demam, kelemahan, batuk, kejang dan diare (WHO, 2020; Repici et al., 2020). Pada Desember 2019, sejumlah pasien dengan pneumonia misterius dilaporkan untuk pertama kalinya di Wuhan, Cina (Phelan, Katz, \& Gostin, 2020). Virus ini telah dinamai sindrom pernapasan akut parah coronavirus 2 (SARS-CoV-2) dan dapat bergerak cepat dari manusia ke manusia melalui kontak langsung (Li et al., 2020; Rothe et al., 2020)

Kejadian kasus Covid-19 terus bertambah dari hari ke hari sehingga petugas kesehatan sebagai garis depan semakin tertekan karena meningkatnya beban kerja, mengkhawatirkan kesehatan mereka, dan keluarga (Cheng et al., 2020). Satu hal yang dapat menyebabkan petugas kesehatan akan mengalami peningkatan kecemasan (Ramadhan, 2020). Petugas kesehatan berisiko mengalami gangguan psikologis dalam merawat pasien Covid-19 karena perasaan depresi, penyebab utamanya adalah perlindungan diri yang masih kurang dari kebutuhan petugas kesehatan (Lai et al., 2020).

Data virus corona di Kota Batam tercatat juga mengalami peningkatan. Hingga Sabtu (26/10/2020) pukul 12.00 WIB, kasus positif Covid-19 bertambah mejadi sebanyak 2.679. Sedangkan untuk kasus sembuh, juga ada penambahan sebanyak 2.019 orang. Pasien yang meninggal dunia karena infeksi
Covid-19 sebanyak 66 orang ( Diskomifo Kepri, 2020).

Didapatkan data pegawai RSUD Embung Fatimah Kota Batam yang terkofirmasi Positif Covid 19 pada tanggal 26/10 /2020 sebanyak 38 orang da perawat sebanyak 13 orang. kasus sembuh sebanyak 12 orang, perawat yang sedang dirawat ada 2 orang.

Respon psikologis yang dialami oleh petugas kesehatan terhadap pandemi penyakit menular semakin meningkat karena disebabkan oleh perasaan cemas tentang kesehatan diri sendiri dan penyebaran keluarga (Cheng et al., 2020). Kecemasan adalah kekhawatiran yang tidak jelas dirasakan oleh seseorang dengan perasaan tidak pasti dan tidak berdaya (Stuart, 2016). Rasa panik dan rasa takut merupakan bagian dari aspek emosional, sedangkan aspek mental atau kognitif yaitu timbulnya gangguan terhadap perhatian, rasa khawatir, ketidakteraturan dalam berpikir, dan merasa binggung (Ghufron dkk, 2014). Sehingga dari kejadian Covid-19 ini tenaga kesehatan merasa tertekan dan khawatir.

Penelitian Ulfiah, dkk (2020) dengan judul Metode Zikir Sebagai Upaya Keluarga Dalam Menghadapi Kecemasan Pandemi Covid-19. Penelitian ini bertujuan untuk menganalisis metode zikir sebagai upaya keluarga dalam menghadapi kecemasan pandemi Covid-19. Hal ini membutuhkan penanganan yang lebih serius.Karena kondisi semua individu berkumpul di rumah, maka penelitian ini mengambil langkah meningkatkan imun keluarga agar terhindar dari kecemasan dan ketakutan yang berkelanjutan, yaitu dengan zikir dalam keluarga. Penelitian ini menggunakan pendekatan partisipatoris karena menggunakan data lapangan dan penelusuran pustaka tentang zikir dan kecemasan. Hasil penelitian menujukkan bahwa zikir dapat dijadikan sebuah metode keluarga dalam menghadapi kecemasan pandemi Covid-19. Zikir keluarga dapat 
dilakukan dalam waktu yang singkat selepas shalat berjamaah, memulai dengan zikir yang sederhana, dilakukan dengan cara konsisten dan presisten.

Penelitian Agustin Ike (2020), dengan judul Studi Kasus Penerapan Kombinasi Terapi Dzikir Pada Pasien Pre Dan Post Operasi Hernia Inguinalis Dengan Ansietas Di Rs Pku Muhammadiyah Sruweng. Didapatkan peningkatan kemampuan pasien 2 dalam melakukan terapi sebelum diberikan terapi dzikir (25\% kurang), peningkatan emampuan pasien 2 dalam melakukan terapi setelah diberikan terapi dzikir (50\% cukup)

Penelitian Arif Syamsul (2018) Pengaruh Terapi Psiko Spiritual : Bacaan Dzikir Terhadap Tingkat Kecemasan Pada Pasien Pre Operasi, Penelitian didapatkan hasil tingkat kecemasan responden sebelum diberikan terapi dzikir kecemasannya berat sekali sebanyak 7 responden $(25,9 \%)$ dan tingkat kecemasannya berat berjumlah 19 responden $(70,4 \%)$. Tingkat kecemasan responden sesudah diberikan terapi dzikir kecemasannya sedang sebanyak 15 responden $(55,6 \%)$ dan tingkat kecemasannya berat sekali berjumlah 1 responden $(3,7 \%)$. Simpulan - Ada pengaruh terapi psiko spiritual :bacaan dzikir terhadap tingkat kecemasan pada pasien pre operasi di Ruang Wawab Hasbullah RSI NU Demak menggunakan uji wilcoxon atau uji beda 2 kelompok berpasangan adalah nilainya 3,716 \&lt; 54,418. Diharapkan perawat dapat terampil melaksanakan terapi psiko spiritual : bacaan dzikir pada pasien pre operasi dengan teknik yang tepat dan efisien.

\section{METODE PENELITIAN}

Asuhan Keperawatan ini menggunakan metode studi kasus. Berlokasi di RSUD Embung Fatimah Kota Batam. penelitian ini dilakukan tanggal 25 - 27 Oktober 2020. Pada asuhan keperawatan ini yang menjadi objek penelitian adalah perawat yang berdinas di ruang covid RSUD Embung Fatimah Kota
Batam. Asuhan keperawatan ini menggunakan metode wawancara dan memberikan terapi sesuai SOP yang telah di sediakan. terapi ini dimulai dengan pasien diminta memilih kalimat spiritual yang akan digunakan, kemudian duduk rileks, lalu menutup kedua mata dan mengendurkan otot serta bernafas secara alami dan mulai mengucapkan kalimat spiritual yang di baca berulang - ulang. lakukan kegiatan ini selama 30 menit.

\section{HASIL DAN PEMBAHASAN}

Pada saat pengkajian tanggal 25 oktober 2020 didapatkan Ny.Z mengatakan cemas dan takut dengan kondisi sekarang yang mana makin lama makin banyak orang yang positif covid-19, Ny.Z merasa gelisah, ia merasa lelah dan susah tidur. Saat pengkajian riwayat kesehatan masa lalu dan riwayat kesehatan keluarga klien tidak ada masalah. konsep diri klien sesuai dan baik. Analisa data yang diperoleh adalah data subjektif : klien mengatakan cemas, mengatakan takut dengan kondisi sekarang yang mana makin lama makin banyak orang yang positif covid19. Data objektif yang di dapat adalah klien tampak cemas, tampak linglung, tampak gelisah, Tekanan darah :110/80mmHg, Nadi :88x/mnt, Suhu :36, $3^{\circ} \mathrm{C}$,Pernafasan $: 20$. $\mathrm{x} / \mathrm{mnt}$. diagnosa yang di angkat berdasarkan data tersebut adalah ansietas. Data subjektif selanjutnya adalah klien mengatakan susah tidur, mengatakan tidur hanya 6 jam dan sering terbangun, data objektifnya Ny.Z tampak lemas, Ny.Z tampak gelisah. diagnosa yang diangkat berdasarkan data tersebut adalah gangguan pola tidur. intervensi yang bisa diberikan untuk diagnosa ansietas adalah Anxiety Reduction (penurunan kecemasan) dengan kriteria hasil yang diharapkan Klien mampu mengidentifikasi dan mengungkapkan gejala cemas, mengidentifikasi, mengungkapkan dan menunjukkan tehnik untuk mengontol cemas, vital sign dalam batas normal, postur tubuh, ekspresi wajah, bahasa tubuh dan tingkat aktivfitas menunjukkan berkurangnya kecemasan (Nicnoc, 2019), sedangkan untuk ganguan pola tidur 
intervensi yang diberikan adalah Sleep Enhancement dengan kriteria hasil jumlah jam tidur dalam batas normal 6-8 jam/hari, pola tidur, kualitas dalam batas normal,perasaan segar sesudah tidur atau istirahat,mampu mengidentifikasikan hal-hal yang meningkatkan tidur. Untuk asuhan keperawatan ini di khususkan pada diagnosa prioritas yakni Ansitas dengan memberikan implementasi pemberian terapi dzikir. Penerapan terapy dzikir pada Ny.I yang dilakukan selama \pm 72 jam sesuai prosedur dapat menurunkan ansietas, didapatkan $\mathrm{ku}$ baik kesadaran composmentis, cemas berkurang, takut berkurang, gelisah sudah mulai hilang, tampak lebih relaks, tampak nyaman, TTV : TD 120/80mmHg, Nadi : $74 x / m n t$, Suhu : $36^{\circ} \mathrm{C}$, Pernafasan:18x/mnt.

\section{KESIMPULAN}

Intervensi yang disusun disesuaikan dengan tinjauan teori dan tinjauan kasus di lapangan, Intervensi dilakukan sesuai dengan teori NANDA NIC NOC dan jurnal selama 3 hari, tidak ada hambatan selama di lakukan intervensi keperawatan. Implementasi pada Ny.N dilakukan selama 3 hari ( tiga kali pertemuan ) sesuai Rencana keperawatan dan terlaksana dengan baik.

\section{UCAPAN TERIMA KASIH}

1. Rektor Institut Kesehatan Mitra Bunda

2. Tim penyusun artikel

3. RSUD Embung Fatimah Batam

\section{REFERENSI}

Ayu Rahmawati Permatasari, Jati Ariati. (2015). Efikasi diri dan Stres kerja pada Relawan PMI Kabupaten Boyolali, Jurnal Empati, Oktober 2015. Volume 4 239-244. https://ejournal3.undip.ac.id/index.php/ empati/article/view/14349. Diakses tanggal 29 mei 2020.

Belfroid, Evelien. (2018). "Positive Experiences of Volunteers Working in Deployable Laboratories in West Africa during the Ebola Outbreak." PLoS ONE 13(4): 1-8.
BNPB. (2014). Berita Negara Republik Indonesia Penanggulangan Bencana Pedoman. https://bnpb.go.id/.

Cheng, Q., Liang, M., Li, Y., He, L., Guo, J., Fei, D., Zhang, Z. (2020). Correspondence Mental health care for medical staff in China during the COVID-19. Lancet, 7, 15-26. https:// doi.org/10.1016/S22150366(20)30078-X

Chua, S., Cheung, V., Mcalonan, G., Tang, S., Cheung, C., McAlonan, G. M., Chang, M. T. (2004). Psychological Effects of the SARS Outbreak in Hong Kong on High-Risk Health Care Workers. The Canadian Journal of Psychiatry, 49(6), 391-393. https://doi.org/ 10.1177/070674370404900609

Gates, B. (2020). Responding to Covid-19-A Once-in-a-Century Pandemic? New England Journal of Medicine, 386(18), 1677-1679.

https://doi.org/DOI:10.1056/NEJMp20 $\underline{03762}$

Ghufron, M. N., \& Risnawita, R. (2014). TeoriTeori Psikologi. Jogjakarta: ArRuzz Media.

Guo, Y., Cao, Q., Hong, Z., Tan, Y., Chen, S., Jin, H., Yan, Y. (2020). The origin , transmission and clinical therapies on coronavirus disease 2019 (COVID-19) outbreak - an update on the status. Military Medical Research, 7(11), 110.

Heymann, D. L. (2020). A novel coronavirus outbreak of global health concern. Lancet, 395, 470-473. https://doi.org/10.1016/S01406736(20)30185-9

IASC. (2020). Catatan tentang aspek kesehatan jiwa dan psikososial wabah Covid-19 (pp. 1-20).

Kemenkes., RI. (2020). Perkembagan Kasus Covid-19 Kumulatif Di Indonesia. Retrieved from http://pusatkrisis.kemkes.go.id/

Lai, J., Ma, S., Wang, Y., Cai, Z., Hu, J., Wei, N., Li, R. (2020). Factors Associated With Mental Health Outcomes Among Health Care Workers Exposed to 
Coronavirus Disease 2019. JAMA, 3(3),

$1-12$. https://doi.org/ 10.1001/jamanetworkopen.2020.3976.

Li, Q., Guan, X., Wu, P., Wang, X., Zhou, L., Tong, Y., Feng, Z. (2020). Early Transmission Dynamics in Wuhan, China, of Novel Coronavirus-Infected Pneumonia. The New England Journal of Medicine, 382(13), 1199- 1207. https://doi.org/10.1056/NEJMoa200131 $\underline{6}$

Lockhart, S. L., Duggan, F. L. V, Wax, F. R. S., Saad, S., \& Grocott, H. P. (2020). Personal protective equipment ( PPE ) for both anesthesiologists and other airway managers: principles and practice during the COVID-19 pandemic. Canadian Journal of Anesthesia.

https://doi.org/10.1007/s12630-02001673-w

Maben, J., \& Bridges, J. (2020). Covid-19: Supporting nurses' psychological and mental health. Journal of Clinical Nursing, 29(10), 1423-1424. https://doi.org/10.1111/jocn.15307

PDPI. (2020). Panduan Praktik Klinis: Pneumonia 2019 n-CoV. Jakarta: PDPI.

Pemprov., SulSel. (2020). Sulsel Tanggap Covid19. 1 S. Pemprov, (2020). Retrieved from https:// covid19.sulselprov.go.id/data

Phelan, L. A., Katz, R., \& Gostin, L. O. (2020). The Novel Coronavirus Originating in Wuhan , China Challenges for Global Health Governance. JAMA, 323(8), 709-710. https:// doi.org/10.1001/jama. 2020.1097

Prompetchara, E., Ketloy, C., \& Palaga, T. (2020). Immune responses in COVID-19 and potential vaccines : Lessons learned from SARS and MERS epidemic. Asian Pacific Journal of Allergy and Immunology, 38, 1-9. https://doi.org/10.12932/ AP-2002200772

Puspanegara, A. (2019). Pengaruh usia terhadap hubungan mekanisme koping dengan kecemasan. Jurnal Ilmu Kesehatan Bhakti Husada, 10(2), 142-
149.

10.34305/JIKBH.V10I2. 102

https://doi.org/

Ramadhan, A. (2020). Vitalnya ketersediaan APD untuk melindungi tenaga kesehatan. Jakarta. Retrieved from https://www.antaranews.com/ berita/1411158/vitalnya-ketersediaanapduntuk-melindungi-tenaga-

kesehatan

Razai, M. S., Doerholt, K., Ladhani, S., \& Oakeshott, P. (2020). Coronavirus disease 2019 ( covid-19 ): a guide for UK. Medical lLadersip and Management, (March), 1-5. https://doi.org/10.1136/bmj.m800

Remuzzi, A., \& Remuzzi, G. (2020). Health Policy COVID-19 and Italy: what next? Health Policy, 2, 10-13. https://doi.org/10.1016/ S01406736(20)30627-9

Repici, A., Maselli, R., Colombo, M., Gabbiadini, R., Spadaccini, M., Anderloni, A., Lagioia, M. (2020a). Coronavirus (COVID-19) outbreak: what the department of endoscopy should know. Gastrointestinal Endoscopy Journal, 1-6. https://doi.org/10.1016/j.gie.2020.03.0 $\underline{19}$

Repici, A., Maselli, R., Colombo, M., Gabbiadini, R., Spadaccini, M., Anderloni, A., Lagioia, M. (2020b). Coronavirus (COVID-19) outbreak: what the department of endoscopy should know. Gastrointestinal Endoscopy, 1-6. https://doi.org/ 10.1016/j.gie.2020.03.019

Rothe, C., Schunk, M., Sothmann, P., Bretzel, G., Froeschl, G., Wallrauch, C., Janke, C. (2020). Transmission of 2019-nCoV Infection from an Asymptomatic Contact in Germany. The New England Journal of Medicine, 382(10). https://doi.org/10.1056/NEJMc200146 8

Shanafelt, T., Ripp, J., Sinai, M., \& Trockel, M. (2020). Understanding and Addressing Sources of Anxiety Among Health Care Professionals During the COVID-19 Pandemic. JAMA. 
https://doi.org/10.1001/ jama.2020.5893

Shereen, M. A., Khan, S., Kazmi, A., Bashir, N., \& Siddique, R. (2020). COVID-19 infection: Origin, transmission, and characteristics of human coronaviruses. Journal of Advanced Research, 24, 9198. j.jare.2020.03.005 https://doi.org/10.1016/

Stuart, G. W. (2016). Prinsip dan Praktik Keperawatan Kesehatan Jiwa. Singapore: Elsevier

WHO. (2020b). The World Health Organization declared the coronavirus outbreak a Global Public Health Emergency. Retrieved from https://www.worldometers.info/coronav irus/

Yuliana. (2020). Corona Virus Diseases (COVIR19): Sebuah tinjauan literatur. Wellness And Healthy Magazine, 2(February), 187-192. Retrieved from https://wellness.journalpress.

id/wellness/article/view/2102 
